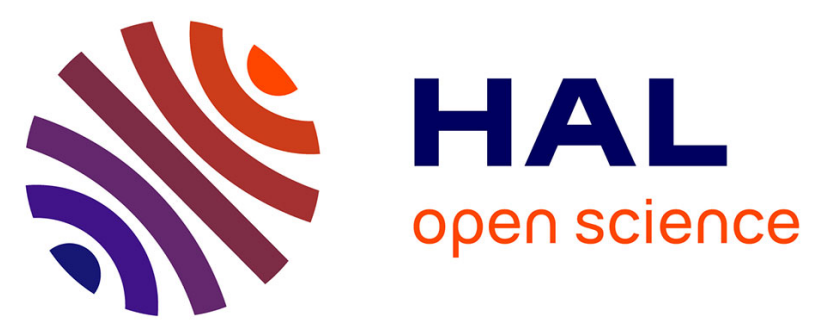

\title{
Use of dipeptidyl peptidase- 4 inhibitors and prognosis of COVID-19 in hospitalized patients with type 2 diabetes: A propensity score analysis from the CORONADO study
}

Ronan Roussel, Patrice Darmon, Matthieu Pichelin, Thomas Goronflot, Yawa Abouleka, Leila Ait Bachir, Ingrid Allix, Deborah Ancelle, Sara Barraud, Lyse Bordier, et al.

\section{- To cite this version:}

Ronan Roussel, Patrice Darmon, Matthieu Pichelin, Thomas Goronflot, Yawa Abouleka, et al.. Use of dipeptidyl peptidase-4 inhibitors and prognosis of COVID-19 in hospitalized patients with type 2 diabetes: A propensity score analysis from the CORONADO study. Diabetes, Obesity and Metabolism, 2021, 23 (5), pp.1162-1172. 10.1111/dom.14324 . hal-03246543

HAL Id: hal-03246543

https://hal.science/hal-03246543

Submitted on 2 Jun 2021

HAL is a multi-disciplinary open access archive for the deposit and dissemination of scientific research documents, whether they are published or not. The documents may come from teaching and research institutions in France or abroad, or from public or private research centers.
L'archive ouverte pluridisciplinaire HAL, est destinée au dépôt et à la diffusion de documents scientifiques de niveau recherche, publiés ou non, émanant des établissements d'enseignement et de recherche français ou étrangers, des laboratoires publics ou privés. 
Use of Dipeptidyl Peptidase-4 inhibitors and prognosis of COVID-19 in hospitalized patients with type 2 diabetes: a propensity score analysis from the CORONADO study

Short running title: Dipeptidyl Peptidase-4 inhibitors and COVID-19 in type 2 diabetes

Ronan Roussel ${ }^{1}$, Patrice Darmon ${ }^{2}$, Matthieu Pichelin ${ }^{3}$, Thomas Goronflot ${ }^{4}$, Yawa Abouleka ${ }^{1}$, Leila Ait Bachir $^{5}$, Ingrid Allix ${ }^{6}$, Deborah Ancelle ${ }^{7}$, Sara Barraud ${ }^{8}$, Lyse Bordier $^{9}$, Aurélie Carlier ${ }^{1}$, Nicolas Chevalier ${ }^{10}$, Christine Coffin-Boutreux ${ }^{11}$, Emmanuel Cosson ${ }^{12}$, Anne Dorange ${ }^{13}$, Olivier Dupuy ${ }^{14}$, Pierre Fontaine ${ }^{15}$, Bénédicte Fremy ${ }^{16}$, Florence Galtier ${ }^{17}$, Natacha Germain ${ }^{18}$, Anne-Marie Guedj ${ }^{19}$, Etienne Larger ${ }^{20}$, Stéphanie Laugier-Robiolle ${ }^{21}$, Bruno Laviolle ${ }^{22}$, Lisa Ludwig ${ }^{23}$, Arnaud Monier ${ }^{24}$, Nathanaëlle Montanier ${ }^{25}$, Philippe Moulin $^{26}$, Isabelle Moura ${ }^{27}$, Gaëtan Prevost ${ }^{28}$, Yves Reznik ${ }^{29}$, Nadia Sabbah ${ }^{30}$, Pierre-Jean Saulnier ${ }^{31}$, Pierre Serusclat $^{32}$, Camille Vatier ${ }^{33}$, Matthieu Wargny ${ }^{4}$, Samy Hadjadj ${ }^{3}$, Pierre Gourdy ${ }^{34}$, Bertrand Cariou ${ }^{3}$ for the CORONADO investigators.

${ }^{1}$ Département d’Endocrinologie, Diabétologie et Nutrition, Hôpital Bichat, Assistance Publique-Hôpitaux de Paris; Centre de Recherche des Cordeliers, INSERM, U-1138; Université de Paris, Paris, France

${ }^{2}$ Service d'Endocrinologie, Maladies Métaboliques et Nutrition, Hôpital de la Conception, Assistance Dublique-Hôpitaux de Marseille; INSERM, INRA, C2VN, Aix-Marseille University, Marseille, France

${ }^{3}$ Département d'Endocrinologie, Diabétologie et Nutrition, l'institut du thorax, INSERM, CNRS, UNIV Nantes, CHU Nantes, Nantes, France

${ }^{4}$ CIC-EC 1413, Clinique des Données, CHU de Nantes, France

Département d’Endocrinologie, Diabétologie, Nutrition, Hôpital Franco-britannique, Levallois-Perret, France

${ }^{6}$ Département d’Endocrinologie, Diabétologie, Nutrition, CHU de Angers, Angers, France

${ }^{7}$ Département d’Endocrinologie, Diabétologie, Nutrition, CH Le Havre, Le Havre, France

${ }^{8}$ CRESTIC EA 3804, Université de Reims Champagne Ardenne, UFR Sciences Exactes et Naturelles, Moulin de la Housse, BP 1039, 51687 Reims CEDEX 2, France ; Centre Hospitalier Universitaire de Reims, Service d'Endocrinologie - Diabète - Nutrition, Avenue du Général Koenig, 51092 Reims Cedex, France

${ }^{9}$ Département d’Endocrinologie, Maladies Métaboliques, Service de Santé des Armées, Hôpital d'instruction des Armées Bégin, Saint Mandé, France

This article has been accepted for publication and undergone full peer review but has not been through the copyediting, typesetting, pagination and proofreading process which may lead to differences between this version and the Version of Record. Please cite this article as doi: $10.1111 /$ dom.14324 
${ }^{10}$ Service d'endocrinologie, diabétologie et médecine de la reproduction, hôpital de l'Archet 2, Université Côte d'Azur, CHU de Nice, Nice, France ; INSERM, UMR U1065/UNS; Université Côte d'Azur, CHU de Nice, Nice, France

${ }^{11}$ Département d'Endocrinologie, Diabétologie, Maladies Métaboliques, CH de Périgueux, Périgueux, France

${ }^{12}$ Département d'Endocrinologie, Diabétologie et Nutrition, CRNH-IdF, CINFO, Hôpital Avicenne, Assistance Publique Hôpitaux de Paris; INSERM, UMR U557; Université Paris 13, Sorbonne Paris Cité, Bobigny, France

${ }^{13}$ Département de Diabétologie, Endocrinologie, CH Le Mans, Le Mans, France

${ }^{14}$ Département d’Endocrinologie, Diabétologie, Paris Hôpital Saint-Joseph, Paris, France

${ }^{15}$ Département d'endocrinologie, Diabète et maladies métaboliques, Hôpital Huriez, Université de Lille, Lille, France

${ }^{16}$ Département d’Endocrinologie, Diabétologie, Nutrition, CH de Agen-Nerac, Agen, France

${ }^{17}$ Centre d'Investigation Clinique et Département des Maladies Endocriniennes, INSERM, CIC 1411, Hôpital St Éloi, CHU Montpellier, Montpellier, France

${ }^{18}$ Département d'Endocrinologie, CHU de Saint-Etienne, Saint-Etienne, France ; TAPE Research Group EA 7423, Université Jean Monnet, Saint-Etienne, France

${ }^{19}$ Département Maladies Métaboliques et Endocriniennes, CHU Nîmes, Nîmes, France

${ }^{20}$ Service de diabétologie, Hôpital Cochin, AP-HP, Centre-Université de Paris, 27, rue du Faubourg-SaintJacques, 75014 Paris, France

${ }^{21}$ Département de Diabétologie, $\mathrm{CH}$ de Auch, Auch, France

${ }^{22}$ Univ Rennes, CHU Rennes, Inserm, CIC 1414 (Centre d'Investigation Clinique de Rennes), Rennes, France

CHRU Nancy, hôpital Brahois, Université de Lorraine, Nancy, France

${ }^{24}$ Département de Diabétologie, Endocrinologie, Nutrition, CH de CHARTRES, Chartres, France

${ }^{25}$ Département de Médecine, CH de Forez, Forez, France

${ }^{26}$ Fédération d'endocrinologie, maladies métaboliques, diabète et nutrition, INSERM UMR 1060 CARMEN Hospices Civils de Lyon, Université Lyon 1- Lyon, France

${ }^{27}$ Unité transversale Diabétologie - Endocrinologie, CH de Albi, Albi, France

${ }^{28}$ Département d’Endocrinologie, Diabétologie et Maladies Métaboliques, CHU de Rouen, Université de Rouen, Rouen, France

${ }^{29}$ Département de Diabétologie, CHU de Caen, Caen, France

${ }^{30}$ Département d’Endocrinologie, Diabétologie, Nutrition, CH de Cayenne, Cayenne, France

${ }^{31}$ Centre d’Investigation Clinique CIC 1402, Université de Poitiers, Inserm, CHU de Poitiers, Poitiers, France 
${ }^{32}$ Groupe Hospitalier Mutualiste Les Portes du Sud, Department of Endocrinology, Diabetology and Nutrition, Vénissieux, France

${ }^{33}$ Assistance Publique Hôpitaux de Paris, Saint-Antoine Hospital, Reference Center of Rare Diseases of Insulin Secretion and Insulin Sensitivity (PRISIS), Department of Endocrinology, Paris; Sorbonne University, Inserm UMRS 938, Saint-Antoine Research Center, Paris, France

34 Département d'Endocrinologie, Diabétologie et Nutrition, CHU Toulouse, Institut des Maladies Métaboliques et Cardiovasculaires, UMR1048 INSERM/UPS, Université de Toulouse, Toulouse, France

Corresponding author: Ronan Roussel, (ronan.roussel@aphp.fr), Endocrinology, Diabetology and

Nutrition, Hôpital Bichat, Assistance Publique-Hôpitaux de Paris, 46 Rue Henri Huchard, 75018 Paris, France or Bertrand Cariou, (bertrand.cariou@univ-nantes.fr) Department of Endocrinology, Diabetology and Nutrition, l’institut du Thorax, CHU Nantes, Hôpital Guillaume et René Laennec, 44093 Nantes Cedex 01, France.

I A complete list of the CORONADO trial investigators is provided in the appendix.

\section{Word count}

Abstract: 255/250

Main text: 2965/3500

References: 32

Tables: 3

rıुนres: 2 


\section{ABSTRACT}

\section{Aims}

Dipeptidyl Peptidase-4 (DPP-4), the target of oral antidiabetic drugs DDP-4 inhibitors, has been suggested to be involved in the pathogenesis of coronavirus infections, including COVID-19. It is unclear whether the routine use of DPP-4 inhibitors increases the severity of COVID-19 in people with type 2 diabetes (T2D). Our purpose was to investigate the association between routine use of DPP-4 inhibitors and the severity of COVID-19 infection in a large multicentric study.

\section{Material and Methods}

This study was a secondary analysis of the CORONADO study on 2449 patients with T2D hospitalized for COVID-19 in 68 French centres. The composite primary endpoint combined tracheal intubation for mechanical ventilation and death within 7 days of admission. Stabilized weights were computed for patients based on propensity score (DPP-4 inhibitors users vs non-users) and were used into multivariable logistic regression models to estimate Average Treatment effect in the Treated as Inverse Probability of Treatment Weighting (IPTW).

\section{Results}

596 participants were under DPP-4 inhibitors before admission to hospital (24.3\%). The primary outcome occurred at similar rates in users and non-users of DPP-4 inhibitors ( $27.7 \%$ vs $28.6 \%, \mathrm{P}=0.68)$. In propensity analysis, the IPTW-adjusted models showed no significant association between use of DPP-4 inhibitors and ue primary outcome within day 7 (OR [95\%CI]: 0.95 [0.77-1.17]) or day 28 (OR [95\%CI]: 0.96 [0.781.17]). Similar neutral findings were found between use of DPP-4 inhibitors and the risk of tracheal intubation and death.

\section{Conclusions}

These data support the safety of DPP-4 inhibitors for diabetes management during the COVID-19 pandemic and they should not be discontinued. 


\section{INTRODUCTION}

Diabetes has been evidenced as one of the main clinical factors associated with severity of coronavirus disease 2019 (COVID-19). Dipeptidyl Peptidase-4 (DPP-4, or CD26), a transmembrane glycoprotein, expressed in endocrine cells, immune cells, endothelial cells, and pneumocytes, among many tissues, is now recognized as a coronavirus receptor protein (1). Its functions, which are incompletely unveiled, include degradation of incretins such as glucagon like peptide-1 (GLP-1) and glucose-dependent insulinotropic polypeptide, but also immune regulation by activation of $\mathrm{T}$ cells, up-regulation of CD86 expression and NF-kappaB pathway, and cleavage of a number of cytokines, chemokines, and growth factors (2). During the former coronavirus epidemics, it was suggested that higher severity of MERS-CoV infection in type 2 diabetes (T2D) could be associated with a DPP-4-mediated dysregulated immune response. The hypothesis was supported by an experimental work, using human-DPP-4-expressing obese mice (3), and also by a genetic association study in patients (4), and has been recently reviewed (5-7). On the other hand, administration of recombinant soluble DPP-4 attenuated lung histopathology in another pre-clinical study (8). This was consistent with the observation of lower circulating levels of soluble DPP-4 in human subjects with MERS-CoV, relative to healthy controls (9).

People with T2D, whether they are obese or not, are commonly treated with DPP-4 inhibitors. There is no evidence for a higher risk of respiratory tract infections associated with the use of this class of antidiabetic drugs according to randomized controlled trials (RCTs) (10) or observational studies (11-12), anhough a 2011 report of the WHO adverse drug reactions database had shown a higher prevalence of upper respiratory tract infections among users of DPP-4 inhibitors compared with users of other antidiabetic drugs (13). Therefore, the effects of DPP4 inhibition on the immune response in patients with T2D remain unclear, and the critical role of regulation of cytokines during the course of COVID-19 with the burst of apparently uncontrolled immune activation a few days after the onset of the symptoms in many severely affected patients has led to a call for caution in the use of DPP-4 inhibitors on one side and the launch of a small clinical randomized trial to assess whether a DPP-4 inhibitor could reduce the severity of COVID-19 on the other side (NCT04341935).

Thus, discrepant messages have been received by health-care providers and people with diabetes. To our knowledge, the clinical evidence they need to guide their decisions regarding their use of DPP-4 inhibitors is still limited to a small neutral case-control study (14). 
Our purpose was to investigate the association between the use of DPP-4 inhibitors and the early severity of illness and mortality in patients with T2D hospitalized for COVID-19 infection, by using propensity score matching in the CORONADO (CORONAvirus and Diabetes Outcomes) study. 


\section{MATERIALS AND METHODS}

\section{Study design and participants}

The current study was a secondary analysis of the CORONADO study (ClinicalTrials.gov NCT04324736), which aimed at describing the phenotype and prognosis of people with diabetes admitted to hospital for COVID-19 and diabetes between 10 March and 10 April 2020. The study was sponsored by CHU Nantes, designed in accordance with the declaration of Helsinki and conducted in accordance with French legislation with approval obtained from the local ethics committee (Institutional Review Board/Institutional Ethics Committee - GNEDS [groupe nantais d'éthique dans le domaine de la santé]), the CEREES (comité d'expertise pour les recherches, les études et les évaluations dans le domaine de la santé; $\mathrm{n}^{\circ}$ INDS [institut national des données de santé]: 1544730) and the CNIL (commission nationale de l'informatique et des libertés; DR-2020-155/920129). A 'non-opposition to participate' was orally collected after informed consent if feasible, according to the recommendation of the ethical committee for this observational study.

Inclusion criteria and design of the CORONADO study have been detailed elsewhere (15). For the purpose of the current sub-analysis, information on routine use of DPP-4 inhibitors (i.e. sitagliptin, vildagliptin and saxagliptin which are commercially available in France) prior to the admission was mandatory for inclusion.

Clinical and biological data have been described previously (15). In the current analysis, $\mathrm{HbA}_{1 c}$ and estimated Glomerular Filtration Rate (eGFR) values correspond to the more recent routine biological determinations in the 6- and 12-months preceding admission, respectively.

\section{suidy outcomes}

The composite primary endpoint combined tracheal intubation for mechanical ventilation and death within 7 days of admission. Secondary outcomes included death on day 7, tracheal intubation on day 7, admission to ICUs and discharge on day 7. In the population still hospitalized on day 7, these outcomes were reassessed until day 28.

\section{Statistical analyses - Propensity score analysis}

Quantitative data were given as mean \pm SD or median $\left[25^{\text {th }}-75^{\text {th }}\right.$ percentile $]$. Categorical variables were given as number (percentage) of participants. Patients were classified in two groups according to the use of DPP-4 inhibitors prior to admission. For between group comparisons, unpaired t-tests or Wilcoxon rank-sum tests were used for quantitative variables, while Fisher's exact tests were used for categorical variables. For missing values, a multiple imputation by chained equation using $\mathrm{R}$ package mice $(7$ replicates with 
“predictive mean matching” and "logistic regression” methods for respectively continuous and binary variables) was performed (16). After a careful study of the performance of imputation, replicates were pooled to get the complete dataset to conduct multivariable analyses.

In order to balance the distributions of baseline covariates between groups and then limit confounding bias in analyses, we estimated a propensity score (PS) with a logistic regression model on sex, age, body mass index (BMI), arterial hypertension, history of ischemic heart disease, history of heart failure, active cancer, treated obstructive sleep apnea (OSA), and use of metformin, sulfonylurea, glucagon-like peptide 1 receptor agonists (GLP-1 RAs), insulin, corticosteroids, renin-angiotensin system blockers, statins, thiazide diuretics, and anti-platelet therapy. In sensitivity analysis, the following complementary variables were added: eGFR using the CKD-EPI formula, diabetes duration, and the latest $\mathrm{HbA}_{1 \mathrm{c}}(<6$ months prior to admission). For each model, these variables were selected based on their relevance in clinical practice and statistically ( $<<0.15$ in univariable association with outcome). We did not include in PS calculation variables that are associated with exposition status but not with the primary endpoint because it might have a counterproductive effect by increasing bias and variance in the estimate of treatment effect (17). Comparability was assessed by analyzing reduction in Standardized Mean Differences (SMD) after PS utilization. Stabilized weights (18) were computed for patients based on overlap weighting method and were used into multivariable logistic regression models to estimate Average Treatment effect in the Treated (ATT) as Inverse Probability of Treatment Weighting (IPTW) (19). In addition, PS was used in Cox models to esimate IPTW-Hazard Ratios, presented in supplemental materials. Proportional hazards assumption has been carefully studied. Analyses were performed using R version 3.6.2, in particular packages PSW (19), hrIPW (20) and ggplot2 (21) to estimate the treatment effect in logistic regression models, in survival models and for figures, respectively. 


\section{RESULTS}

\section{Baseline characteristics}

The study population consisted of 2449 patients with T2D declaring the use of at least one antidiabetic drug prior to hospital admission for COVID-19, and available information on the primary outcome at day 7 after admission (see flow chart, Figure 1). Among them, 596 were under DPP-4 inhibitors (24.3\%), mainly under sitagliptin ( $n=424,17.2 \%)$. The baseline characteristics of the patients according to the use of DPP-4 inhibitors are shown in Table 1. Patients using DPP-4 inhibitors were less frequently women (32.6 vs 37.1\% in non-users, $\mathrm{P}=0.0455)$, had a lower median $\mathrm{BMI}$, had less frequently a history of severe diabetic retinopathy, peripheral artery disease or non-alcoholic fatty liver disease. As expected, treatment patterns were strikingly different for antidiabetic but also cardiovascular therapies. DPP-4 inhibitors users were more frequently under metformin and less frequently under GLP-1 RAs or insulin therapy. In addition, they were more frequently under renin-angiotensin-aldosterone system (RAAs) blockers and less frequently under beta blockers. On admission, patients under DPP-4 inhibitors appeared to have a slightly more severe form of infection at admission, with higher plasma glucose and CRP concentrations, two biological markers which have been associated to poorer COVID-19 prognosis (15) (Table 2). The information on how the DPP-4 inhibitors were handled during the hospitalization could be recorded in 455 patients: 358 (81\%) remained on treatment, including those who have had a transitory suspension $(n=147$ [33\%]) or a change in dosage $(n=14$ [3\%]); while 84 (19\%) have stopped the treatment.

\section{Clinical outcomes according to the use of DPP-4 inhibitors}

The primary outcome (tracheal intubation for assisted mechanical ventilation or death on day 7 after admission) occurred at similar rates in users and non-users of DPP-4 inhibitors ( $27.7 \%$ vs $28.6 \%, \mathrm{P}=0.6765)$. The same was true for each component of the primary outcome taken individually (see supplemental Table 1). The pattern was similar when outcomes were reassessed at day 28, except a trend for a non-significant reduction of mortality in DPP-4 inhibitors users (18.1\% vs $21.8 \%, \mathrm{P}=0.0561)$ (supplemental Table 1).

\section{Propensity score analysis}

Because the use of DPP-4 inhibitors and outcomes were significantly associated with some baseline characteristics that can alter the severity of COVID-19, we conducted a complete-case PS analysis to balance 
baseline distributions of age, sex, body mass index, history of heart failure, arterial hypertension or ischemic heart disease, active cancer and also regarding treatments for obstructive apnea, anti-platelet therapy and the use of metformin, insulin, sulfonylurea, renin-angiotensin system blockers, statins, corticosteroids and thiazide diuretics. Supplemental Tables 2, 3 and 5 allow comparisons of baseline characteristics and outcomes between patients not included in multivariable analyses and the complete-case sample with reference to the previously mentioned variables. We performed a multiple imputation for the missing values. As shown in the Figure 2, the reduction in SMD after using IPTW in models illustrated the gain in comparability between groups on baseline covariates. The IPT-Weighted models at day 7 showed no association between use of DPP-4 inhibitors and the primary outcome or its individual component, even after further adjustment on kidney function (i.e. GFR values), diabetes duration and $\mathrm{HbA}_{1 \mathrm{c}}$ (Table 3). 


\section{DISCUSSION}

In the present study, we reported evidence supporting safety of the use of DPP-4 inhibitors prior to hospitalization for COVID-19 in people with T2D. These results, based on the largest cohort analyzed so far to test the safety of this class of drugs during the course of the SARS-Cov-2 pandemics, thus provide reassurance in that regard.

The prevalence of the use of DPP-4 inhibitors in patients with T2D requiring hospitalization for COVID-19 from the CORONADO cohort was slightly lower than what was reported in previous observational studies in France (24.3\% vs 32\% in Roussel et al., mostly sitagliptin (22), and 27\% in Overbeek et al. (23)). This is not suggestive of an increased risk of severe form of COVID-19 due to the use of DPP-4 inhibitors in the community, prior to the admission to the hospital. This finding was also consistent with a recent observational study from Italy (14). In this work, similar rates of treatment with DPP-4 inhibitors were reported in people hospitalized for COVID-19 and in several control groups of people with diabetes in the community and requiring hospitalization for other causes of pneumonia.

In people with diabetes, prior studies suggested the lack of association between the use of DPP-4 inhibitors and the occurrence of community-acquired pneumopathy from any cause $(12,24)$ but also specifically due to SARS-CoV-2 (14). Furthermore, recent observations reported either a reduced mortality rate $(25,26)$ or a neutral effect $(27,28)$ associated with the use of DPP-4 inhibitors prior or during hospitalization for COVID19, in patients with T2D. The literature already includes papers questioning a wide use of the class for preventing COVID and its complications (29). As thoroughly discussed in a commentary paper (30), all these studies have strong limitations (some of which were shared by our current work, first of all their observational nature). These limitations were likely balanced with the potential importance of their messages during the editorial process, due to the emergency of the still raging pandemics. Calls for randomized trials have been made, but they will take time to be delivered, and the community is in urgent need of more evidence meanwhile.

In the CORONADO study, participants on routine DPP-4 inhibitors showed a few traits at admission presumed to be associated with a severe illness, as higher prevalence of fatigue, lower lymphocyte count, higher plasma D-dimer, glucose and CRP concentrations. These features underline the imperative need of statistical methods to control for different characteristics in participants according to the use of DPP-4 inhibitors with the aim of limiting residual confounding factors. Here, we used multivariable logistic regression models to 
estimate Average Treatment effect in the Treated as Inverse Probability of Treatment Weighting, elsewhere described to be less biased and associated with a lowest variance than other PS based methods (31, 32). With this approach, we observed similar rates of the primary outcome (combined tracheal intubation and/or death) as well as its individual components (i.e. tracheal intubation and death) both within 7- and 28-days after admission. We also observed a significant $47 \%$ reduction of all-cause death on day 28 after admission (OR: $0.53[0.31-0.89]$ )-but not on day 7 (OR: 0.56 [0.28-1.12]) (Table 3). Nonetheless, we definitively would not draw any definitive conclusion due to the observational design, the secondary nature of these analyses and their borderline significance. Complete-case analyses also reduce the scope for inference of results with respect to the target population.

The possibility of a reduction in the severity of COVID associated with in-hospital treatment with DPP-4 inhibitors have raised an important issue, although again challenged due to limitations of the study design (6, 25, 26). Indeed, COVID-19 is a multi-organ disease, and beside respiratory failure, which could lead eventually to tracheal intubation and supportive ventilation, other processes may cause death like thrombotic disease. Therefore, we could speculate that DPP-4 inhibitors could limit the damages triggered by the SARS$\mathrm{CoV}-2$ at the systemic level, beyond the lung. Unfortunately, the challenges of clinical care in hospitals at the peak of the epidemics in France have made less accurate than usually the exploration in critical settings, and eventually the death reports. Therefore, they were not collected in the current study. However, experimental and further confirmatory epidemiological data are strongly required to validate the hypothesis raised nicre.

As highlighted before, our study presents some limitations that should be reminded. CORONADO is an observational study which collected data from people with diabetes and COVID-19 at admission in a large number of hospitals in France. As such, it cannot provide insight on the outcomes of COVID-19 in the community. Moreover, it was not feasible to reliably collect extensive data on the use of antidiabetic drugs during the hospital stay and after hospital discharge, if any. Therefore, we cannot study the relationship between in-hospital exposure to any specific drug, including DPP-4 inhibitors, and outcomes. Even while the data is not exhaustive, it seems that a large majority (>80\%) of patients remained on DPP-4 inhibitors after admission to hospital. In addition, our experience showed that most of the patients with diabetes were switched to insulin therapy soon after their admission. Ultimately, routine prescription of drugs does not mean that they were duly taken by patients. Drug compliance was not evaluated in this study. 
Consistently with recently published evidence, the current findings did not identify any deleterious association between treatment with DPP-4 inhibitors and severe outcomes of COVID-19 in patients with T2D admitted to the hospital. These data support safe use of this class of drugs for treating diabetes during the COVID-19 pandemic and they should not be discontinued. Actually, taken together, these observational studies suggest that DPP4 inhibition could carry health benefits in the treatment of COVID-19. Thus, basic and clinical research resources should be dedicated to test this hypothesis. 


\section{ACKNOWLEDGMENTS}

We thank the sponsor of the study (DRCI [délégation à la recherche clinique et à l'innovation] CHU Nantes), the Clinical Project Manager (M. Saignes) and assistant (J. Saunier), Clinical Research Associates (S. El Andaloussi, J. Martin-Gauthier, E. Rebouilleau) and data-managers (B. Guyomarc'h, T. Roman). We acknowledge all medical and clinical research staff involved in the diagnosis and treatment of patients with COVID-19 in participating centers. We thank all of the general practitioners, specialists, pharmacists and biological laboratories responsible for hospitalized patients for providing additional medical information to investigators. We thank the Société Francophone du Diabète (SFD) and Société Française d'Endocrinologie (SFE) for disseminating the study design and organization, and the Fédération Française des Diabétiques (FFD) for participating in the organization of the study.

\section{Funding sources}

This study received the following funding: the Fondation Francophone de Recherche sur le Diabète (FFRD), supported by Novo Nordisk, MSD, Abbott, AstraZeneca, Lilly and FFD (Fédération Française des Diabétiques) - CORONADO initiative emergency grant; Société Francophone du Diabète (SFD) - CORONADO initiative emergency grant; Air Liquide Health Care international. CORONADO initiative emergency grant; Allergan. CORONADO initiative emergency grant; AstraZeneca. CORONADO initiative emergency grant; Elivie. CORONADO initiative emergency grant; Fortil. CORONADO initiative emergency grant; Lifescan. CORONADO initiative emergency grant; Nantes Métropole. CORONADO initiative emergency grant; NHC. CORONADO initiative emergency grant; Novo Nordisk. CORONADO initiative emergency grant; Sanofi. CORONADO emergency grant; PHRC National COVID-19 Hospitalization and Care Organization Division (DHOS) as part of the Hospital Clinical Research Program (PHRC COVID-19-200138). All research facilities are acknowledged for providing research associates and research technicians for clinical investigations pro bono. The funders of the study had no role in study design, data collection, data analysis, data interpretation or writing of the report.

\section{AUTHORS CONTRIBUTION}

Drs B. Cariou and R. Roussel had full access to all of the data in the study and take responsibility for the integrity of the data and the accuracy of the data analysis. Concept and design: B. Cariou, P. Darmon, P. 
Gourdy, S. Hadjadj, M. Pichelin, R. Roussel, M. Wargny. Acquisition, analysis, or interpretation of data: on behalf of the scientific committee of the study (the list of scientific comittee is available on ESM). Drafting of the manuscript: B. Cariou, P. Darmon, P. Gourdy, S. Hadjadj, M. Pichelin, R. Roussel, M. Wargny. Critical revision of the manuscript for important intellectual content: all co-authors. Statistical analysis: M. Wargny, T Goronflot. Patient recruitment: Y. Abouleka, Leila Ait Bachir, I. Allix, D. Ancelle, S. Barraud, L. Bordier, A. Carlier, N. Chevalier, C. Coffin Boutreux, E. Cosson, A. Dorange, O. Dupuy, P. Fontaine, B. Fremy, F. Galtier, N. Germain, A.M. Guedj, E. Larger, S. Laugier-Robiolle, B. Laviolle, L Ludwig, A. Monier, N. Montanier, P. Moulin, I. Moura, G. Prevost, Y. Reznik, N. Sabbah, P.J. Saulnier, P. Serusclat, C. Vatier, S. Hadjadj, P. Gourdy, B. Cariou. Fundraising: B. Cariou, P. Gourdy, S. Hadjadj, M. Pichelin and B. Bauduceau.

\section{CONFLICT OF INTEREST}

RR reports grants, personal fees and non-financial support from Sanofi, Novo Abbott, Applied Therapeutics, Astra-Zeneca, Diabnext, Eli Lilly, Janssen, Medtronic, MSD, Mundipharma, Novo Nordisk, and Servier. PD reports personal fees and non-financial support from Abbott, AstraZeneca, Boehringer Ingelheim, Eli Lilly, MSD, Mundipharma, Novartis, Novo Nordisk, and Sanofi. MP reports grants, non-financial support or personal fees from Air Liquid, Allergan, Amgen, Elivie, Fortil, Lifescan, NHC, Novo Nordisk, and Sanofi. LB non-financial support or personal fees from Abbott, Astra Zeneca, Becton Dickinson, Boehringer Ingelheim,

Lilly, MSD, Novartis, Novo Nordisk, and Sanofi. CCB reports grants, non-financial support or personal fees from AstraZeneca, Novo Nordisk, Sanofi, Eli Lilly, Orkyn, and Medtronic. EC reports non-financial support or personal fees from Abbott, AlphaDiab, Air Liquide, Ascencia, Astra Zeneca, Bezins, BMS, Eli Lilly, LifeScan, Medtronic, MSD, Novartis, Novo-Nordisk, Roche Diagnostics, Sanofi, and YpsoMed. BF reports non-financial support or personal fees from AstraZeneca, Eli Lilly, Isis, Merck, MSD, NHC, Novo Nordisk, Orkyn, Pfizer, Sanofi, Servier, and Vitalaire. PF reports non-financial support or personal fees from Astra Zeneca, Bayer, Eli Lilly, MSD, Novartis, Novo Nordisk, and Sanofi. GP reports non-financial support or personal fees from Abbott, AstraZeneca, Eli Lilly, MSD, Medtronic, Novo Nordisk, and Sanofi. PS reports non-financial support or personal fees from Novo Nordisk, Eli Lilly, AstraZeneca, and MSD. MW reports grants, personal fees from Air Liquid, Allergan, Elivie, Fortil, Lifescan, NHC, Novo Nordisk, and Sanofi. SH reports grants, non-financial support or personal fees from Air Liquid, Allergan, Astra Zeneca, 
Bayer, Boehringer Ingelheim, Dinno Santé, Eli Lilly,Elivie, Fortil, Lifescan, LVL, Merck Sharpe Dome, NHC, Novartis, Pierre Fabre Santé, Sanofi, Servier, and Valbiotis. PG reports grants or personal fees from Abbott, Air Liquid, Allergan, Amgen, Astra-Zeneca, Boehringer Ingelheim, Eli Lilly, Elivie, Fortil, Lifescan, Merck Sharp and Dohme, Mundipharma, NHC, Novo Nordisk, Sanofi, and Servier. BC reports grants, non-financial support or personal fees from Abbott, Allergan, Amgen, Akcea AstraZeneca, Pierre Fabre, Genfit, Gilead, Eli Lilly, Elivie, Fortil, Lifescan, Merck Sharpe Dome, NHC, Novo Nordisk, Regeneron and Sanofi. The other authors had nothing to disclose. 


\section{REFERENCES}

1. Mulvihill EE, Drucker DJ. Pharmacology, physiology, and mechanisms of action of dipeptidyl peptidase-4 inhibitors. Endocr Rev 2014;35(6):992-1019

2. Broxmeyer HE, Capitano M, Campbell TB, Hangoc G, Cooper S. Modulation of hematopoietic chemokine effects in vitro and in vivo by DPP-4/CD26. Stem Cells Dev 2016;25(8):575-585

3. Li K, Wohlford-Lenane C, Perlman S, Zhao J, Jewel AK, Reznikov LR, Gibson-Corley N, Meyerholz DK, McCray Jr PB. Middle east respiratory syndrome coronavirus causes multiple organ damage and lethal disease in mice transgenic for human dipeptidyl peptidase 4. J Infect Dis 2016;213(5):712-722

4. Kleine-Weber H, Schroeder S, Krüger N, Prokscha A, Naim HY, Müller MA, Drosten C, Pöhlmann S, Hoffmann M. Polymorphisms in dipeptidyl peptidase 4 reduce host cell entry of Middle East respiratory syndrome coronavirus. Emerg Microbes Infect 2020;9(1):155-168

5. Drucker DJ. Coronavirus infections and type 2 diabetes - shared pathways with therapeutic implications. Endocrine Rev 2020;41(3):457-470

6. Solerte SB, Di Sabatino A, Galli M, Fiorina P. Dipeptidyl peptidase-4 (DPP4) inhibition in COVID19. Acta Diabetologica 2020; 57(7):779-783

7. Filardi T, Morano S. COVID-19: is there a link betwen the course of infection and pharmacological agents in diabetes? J Endocrinol Invest 2020;43(8):1053-1060

8. Pascal KE, Coleman CM, Mujica AO, Kamat V, Badithe A, Fairhurst J, Hunt C, Strein J, Berrebi A, Sisk JM, Matthews KL, Babb R, Chen G, Lai KMV, Huang TT, Olson W, Yancopoulos GD, Stahl N, Frieman MB, Kyratsous CA. Pre- and postexposure efficacy of fully human antibodies against Spike protein in a novel humanized mouse model of MERS-CoV infection. Proc Natl Acad Sci U S A 2015;112(28):8738-8743

9. Inn KS, Kim Y, Aigerim A, Park U, Hwang ES, Choi MS, Kim YS, Cho NY. Reduction of soluble dipeptidyl peptidase 4 levels in plasma of patients infected with Middle East respiratory syndrome coronavirus. Virology 2018;518:324-327

10. Yang W, Cai X, Han X, Ji L. DPP-4 inhibitors and risk of infections: a meta-analysis of randomized controlled trials. Diabetes Metab Res Rev 2016;32:391-404

11. Gamble JM, Donnan JR, Chibrikov E, Twells LK, Midodzi WK, Majumdar SR. Comparative Safety of Dipeptidyl Peptidase-4 Inhibitors Versus Sulfonylureas and Other Glucose-lowering Therapies for Three Acute Outcomes. Sci Rep 2018;8(1):15142. doi: 10.1038/s41598-018-33483-y.

12. Faillie JL, Filion KB, Patenaude V, Ernst P, Azoulay L. Dipeptidyl peptidase-4 Inhibitors and the Risk of Community-Acquired Pneumonia in Patients With Type 2 Diabetes. Diabetes Obes Metab 2015;17(4):379-85

13. Willemen MJ, Mantel-Teeuwisse AK, Straus SM, Meyboom RH, Egberts TC, Leufkens HG. Use of Dipeptidyl peptidase-4 Inhibitors and the Reporting of Infections: A Disproportionality Analysis in the World Health Organization VigiBase. Diabetes Care 2011;34(2):369-74

14. Fadini GP, Morieri ML, Longato E, Bonora BM, Pinelli S, Selmin E, Voltan G, Falagusta D, Tresso S, Costantini G, Sparacino G, Di Camillo B, Tramontan L, Cattelan AM, Vianello A, Fioretto P, Vettor R, Avogaro A. Exposure to dipeptidyl-peptidase 4 inhibitors and COVID-19 among people with type 2 diabetes: a case-control study. Diabetes Obes Metab 2020 May 28;10.1111/dom.14097. doi: 10.1111/dom.14097. Online ahead of print.

15. Cariou B, Hadjadj S, Wargny $M$ et al, for the CORONADO Investigators. Phenotypic characteristics and prognosis of inpatients with COVID-19 and diabetes: the CORONADO study. Diabetologia 2020;63(8):1500-1515

16. van Buuren S, Groothuis-Oudshoorn K. mice: Multivariate Imputation by Chained Equations in R. Journal of Statistical Software 2011; 45: 1-67 (https://www.jstatsoft.org/v45/i03/)

17. Myers JA, Rassen JA, Gagne JJ, Huybrechts KF, Schneeweiss S, Rothman KJ, Joffe MM, Glynn RJ. 
Effects of adjusting for instrumental variable on bias and precision of effect estimates. Am J Epidemiol 2011; 174: 1213-1222.

18. Li K, Morgan KL, Zaslavsky AM. Balancing covariates via propensity score weighting. Journal of the American Statistical Association 2018; 113: 521.

19. Mao H, Li L. PSW: Propensity Score Weighting Methods for Dichotomous Treatments. R package version 1.1-3. 2018. https://CRAN.R-project.org/package=PSW

20. David Hajage. hrIPW: Hazard ratio Estimation using Cox Model Weighted by the Estimated Propensity Score. R package version 0.1.3. 2020; htpps://CRAN.R-project.org/package=hrIPW

21. Wickham H. ggplot2: Elegant Graphics for Data Analysis. Springer-Verlag New York, 2016.

22. Roussel R, Fontaine P, Gouet D, Serusclat P, Martinez L, Detournay N, Martin-Kristensen M. Treatment of type 2 diabetes in France: More dynamic than inert; analysis of prescription data for 847,122 patients. Médecine des Maladies Métaboliques 2018;12(4): 346-352

23. Overbeek JA, Heintjes EM, Prieto-Alhambra D, Blin P, Lassalle R, Hall GC, Lapi F, Bianchini E. Type 2 diabetes mellitus treatment patterns across Europe: a population-based multi database study. Clin Ther 2017;39(4):759-770

24. Morieri ML, Bonora BM, Longato E, Di Camilo B, Sparacino G, Tramontan L, Avogaro A, Fadini GP. Exposure to dipeptidyl-peptidase 4 inhibitors and the risk of pneumonia among people with type 2 diabetes: retrospective cohort study and meta-analysis. Diabetes Obes Metab 2020; doi: 10.1111/dom.14142.

25. Solerte SB, D’Addio F, Trevisan R, Lovati E, Rossi A, Pastore I, et al. Sitagliptin treatment at the time of hospitalization was associated with reduced mortality in patients with type 2 diabetes and COVID-19: a multicentre, case-control, retrospective, observational study. Diabetes Care 2020; 43: 2999-3006.

26. Mirani M, Favacchio G, Carrone F, Betella N, Biamonte E, Morenghi E, Mazziotti G, Lania AG. Impact of comorbidities and glycemia at admission and dipeptidyl peptidase 4 inhibitors in patients with type 2 diabetes with COVID-19: a case series from an academic hospital in Lombardy, Italy. Diabetes Care 2020 Oct 6, doi: 10.2337/dc20-1340.

27. Kim MK, Jeon JH, Kim SW, et al. The clinical characteristics and outcomes of patients with moderate-to-severe coronavirus disease 2019 infection and diabetes in Daegu, South Korea. Diabetes Metab J 2020; 44: 602-613.

28. Yan H, Valdes AM, Vijay A, et al. Role of drugs used for chronic disease management on susceptibility and severity of COVID-19: a large case-control study. Clin Pharmacol Ther 2020; doi: 10.1002/cpt.2047.

29. Smelcerovic A, Kocic G, Gajic M, Tomovic K, Djordjevic V, Stankovic-Djordjevic D, Anderluh M. DPP-4 inhibitors in the prevention/treatment of pulmonary fibrosis, heart and kidney injury caused by COVID-19 - A therapeutic approach of choice in type 2 diabetic patients? Front Pharmacol 2020; 11:1185.

30. Nauck MA, Meier J. Reduced COVID-19 mortality with sitagliptin treatment? Weighing the dissemination of potentially lifesaving findings against the assurance of high scientific standards. Diabetes Care 2020 Oct 8, doi: 10.2337/dci20.0062.

31. Austin PC. The performance of different propensity-score methods for estimating differences in proportions (risk differences or absolute risk reductions) in observational studies. Statistics in Medicine 2010;29:2137-2148

32. Abdia Y, Kulasekera KB, Datta S, Boakye M, Kong M. Propensity scores based methods for estimating average treatment effect and average treatment effect among treated: A comparative study. Biometrical Journal 2017;59:967-985 


\section{LEGENDS TO FIGURES}

FIGURE 1. Study Flowchart

FIGURE 2. Baseline characteristics balance between DPP4-inhibitors users and non-users after propensity score use in models as inverse probability of treatment weighting. 


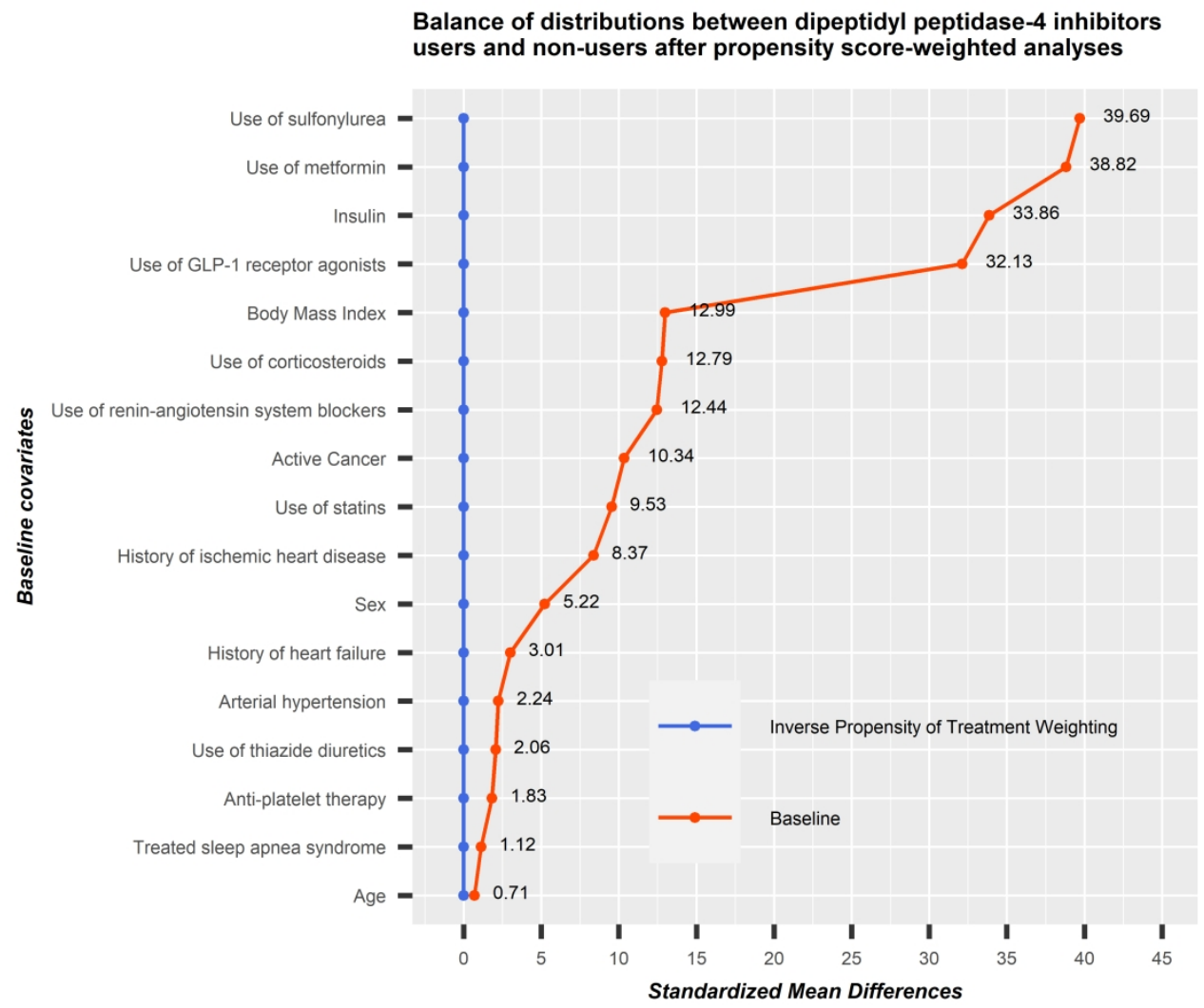

Figure 2: Balance of distributions between Dipeptyl Peptidase-4 inhibitors users and non-users after propensity score-weighted analyses 
Table 1. Clinical characteristics prior to admission of CORONADO participants according to the use of DPP-4 inhibitors

\begin{tabular}{|c|c|c|c|c|c|c|}
\hline & & & \multicolumn{4}{|c|}{ DPP4-inhibitor before admission } \\
\hline Clinical features & $\begin{array}{c}\text { Available } \\
\text { data }\end{array}$ & All & No $(n=1853)$ & Yes $(n=596)$ & $P$ value & $S M D$ \\
\hline Sex (female) & 2449 & $881 / 2449(36 \%)$ & $687 / 1853(37.1 \%)$ & $194 / 596(32.6 \%)$ & 0.0455 & 9.5 \\
\hline Age (years) & 2449 & $70.9+/-12.5$ & $71.1+/-12.8$ & $70.3+/-11.5$ & 0.2339 & 6.3 \\
\hline Ethnicity & 2095 & & & & 0.2478 & 4.1 \\
\hline EU & & $1229 / 2095(58.7 \%)$ & 933/1587 (58.8\%) & \multicolumn{2}{|c|}{$296 / 508(58.3 \%)$} & \\
\hline MENA & & $446 / 2095(21.3 \%)$ & $345 / 1587(21.7 \%)$ & $101 / 508(19.9 \%)$ & 0.5405 & \\
\hline $\mathrm{AC}$ & & $339 / 2095(16.2 \%)$ & $244 / 1587(15.4 \%)$ & $95 / 508(18.7 \%)$ & 0.1382 & \\
\hline AS & & $81 / 2095(3.9 \%)$ & $65 / 1587(4.1 \%)$ & $16 / 508(3.1 \%)$ & 0.3765 & \\
\hline BMI $\left(\mathrm{kg} / \mathrm{m}^{2}\right)$ & 2150 & $28.7[25.3 ; 32.7]$ & $28.9[25.5 ; 33.1]$ & $28.0[24.9 ; 31.6]$ & 0.0045 & 15.9 \\
\hline Diabetes duration (years) & 1483 & $13.9+/-9.6$ & $14.1+/-9.9$ & $13.2+/-8.3$ & 0.1274 & 9.9 \\
\hline $\mathrm{HbA}_{1 \mathrm{c}}(\mathrm{mmol} / \mathrm{mol})$ & 1552 & $64.8+/-20.1$ & $64.3+/-19.8$ & $66.5+/-21.1$ & 0.0808 & 11 \\
\hline $\mathrm{HbA}_{1 \mathrm{c}}(\%)$ & 1552 & $8.1+/-1.8$ & $8+/-1.8$ & $8.2+/-1.9$ & 0.0808 & 11 \\
\hline $\begin{array}{l}\text { eGFR (CKD-EPI), } \\
\mathrm{mL} / \mathrm{min} 1.73 \mathrm{~m}^{2}\end{array}$ & 1606 & $68.0+/-29.4$ & $67.7+/-29.7$ & $69.1+/-28.3$ & 0.8628 & 4.8 \\
\hline Hypertension & 2429 & $1947 / 2429(80.2 \%)$ & $1472 / 1836(80.2 \%)$ & $475 / 593(80.1 \%)$ & 0.969 & 0.2 \\
\hline Dyslipidemia & 2375 & $1173 / 2375(49.4 \%)$ & $892 / 1796(49.7 \%)$ & $281 / 579(48.5 \%)$ & 0.6351 & 2.3 \\
\hline Tobacco use & 2005 & $113 / 2005(5.6 \%)$ & $86 / 1532(5.6 \%)$ & $27 / 473(5.7 \%)$ & 0.9378 & 0.4 \\
\hline $\begin{array}{l}\text { Microvascular } \\
\text { complications }{ }^{\dagger}\end{array}$ & 1724 & $782 / 1724(45.4 \%)$ & $606 / 1319(45.9 \%)$ & $176 / 405(43.5 \%)$ & 0.3793 & 5 \\
\hline $\begin{array}{l}\text { Macrovascular } \\
\text { complications }\end{array}$ & 2308 & $923 / 2308(40.0 \%)$ & $719 / 1748(41.1 \%)$ & $204 / 560(36.4 \%)$ & 0.0482 & 9.7 \\
\hline \multicolumn{7}{|l|}{ Comorbidities } \\
\hline Heart failure & 2329 & $280 / 2329(12.0 \%)$ & $217 / 1760(12.3 \%)$ & $63 / 569(11.1 \%)$ & 0.4229 & 3.9 \\
\hline NAFLD & 2078 & $158 / 2078(7.6 \%)$ & $132 / 1577(8.4 \%)$ & $26 / 501(5.2 \%)$ & 0.0205 & 12.7 \\
\hline Liver cirrhosis & 2301 & $62 / 2301(2.7 \%)$ & $49 / 1743(2.8 \%)$ & $13 / 558(2.3 \%)$ & 0.5416 & 3 \\
\hline Active cancer & 2405 & $233 / 2405(9.7 \%)$ & $188 / 1819(10.3 \%)$ & $45 / 586(7.7 \%)$ & 0.0596 & 9.3 \\
\hline COPD & 2394 & $233 / 2394(9.7 \%)$ & $185 / 1809(10.2 \%)$ & $48 / 585(8.2 \%)$ & 0.1524 & 7 \\
\hline Treated OSA & 2268 & $255 / 2268(11.2 \%)$ & $194 / 1713(11.3 \%)$ & $61 / 555(11 \%)$ & 0.8285 & 1.1 \\
\hline \multicolumn{7}{|l|}{$\begin{array}{l}\text { Routine treatment before } \\
\text { admission }\end{array}$} \\
\hline Sulfonylurea/glinide & 2449 & $754 / 2449(30.8 \%)$ & $493 / 1853(26.6 \%)$ & $261 / 596(43.8 \%)$ & $<0.0001$ & 36.6 \\
\hline Metformin & 2449 & $1496 / 2449(61.1 \%)$ & $1048 / 1853(56.6 \%)$ & $448 / 596(75.2 \%)$ & $<0.0001$ & 40 \\
\hline GLP-1 RA & 2449 & $242 / 2449(9.9 \%)$ & $222 / 1853(12.0 \%)$ & $20 / 596(3.4 \%)$ & $<0.0001$ & 32.8 \\
\hline Insulin therapy & 2449 & $902 / 2449(36.8 \%)$ & $749 / 1853(40.4 \%)$ & $153 / 596(25.7 \%)$ & $<0.0001$ & 31.7 \\
\hline Acarbose & 2449 & $31 / 2449(1.3 \%)$ & $16 / 1853(0.9 \%)$ & $15 / 596(2.5 \%)$ & 0.0048 & 12.9 \\
\hline Thiazide diuretic§ & 2449 & $494 / 2449(20.2 \%)$ & $366 / 1853(19.8 \%)$ & $128 / 596(21.5 \%)$ & 0.3615 & 4.3 \\
\hline Loop diuretic & 2449 & $495 / 2449(20.2 \%)$ & $388 / 1853(20.9 \%)$ & $107 / 596(18.0 \%)$ & 0.1147 & 7.5 \\
\hline MRA & 2449 & $113 / 2449(4.6 \%)$ & $84 / 4853(4.5 \%)$ & $29 / 596(4.9 \%)$ & 0.7366 & 1.6 \\
\hline $\mathrm{ARB}$ and/or ACE inhibitor & 2449 & $1422 / 2449(58.1 \%)$ & $1052 / 1853(56.8 \%)$ & $370 / 596(62.1 \%)$ & 0.0225 & 10.8 \\
\hline Beta blocker & 2449 & $919 / 2449(37.5 \%)$ & $726 / 1853(39.2 \%)$ & $193 / 596(32.4 \%)$ & 0.0029 & 14.2 \\
\hline Calcium Channel Blocker & 2449 & $855 / 2449(34.9 \%)$ & $645 / 1853(34.8 \%)$ & $210 / 596(35.2 \%)$ & 0.8822 & 0.9 \\
\hline Statin & 2449 & $1192 / 2449(48.7 \%)$ & $882 / 1853(47.6 \%)$ & $310 / 596(52.0 \%)$ & 0.0608 & 8.8 \\
\hline
\end{tabular}




\begin{tabular}{|c|c|c|c|c|c|c|}
\hline Anti-platelet agent & 2449 & $1039 / 2449(42.4 \%)$ & $780 / 1853(42.1 \%)$ & $259 / 596(43.5 \%)$ & 0.5583 & 2.8 \\
\hline Vitamin $\mathrm{K}$ antagonist & 2449 & $135 / 2449(5.5 \%)$ & $108 / 1853(5.8 \%)$ & $27 / 596(4.5 \%)$ & 0.2567 & 2.8 \\
\hline $\begin{array}{r}\text { Oral direct factor Xa } \\
\text { inhibitor }\end{array}$ & 2449 & $230 / 2449(9.4 \%)$ & $181 / 1853(9.8 \%)$ & $49 / 596(8.2 \%)$ & 0.2940 & 5.4 \\
\hline Corticosteroid & 2449 & $129 / 2449(5.3 \%)$ & $109 / 1853(5.9 \%)$ & $20 / 596(3.4 \%)$ & 0.0178 & 12.1 \\
\hline $\begin{array}{r}\text { COPD and/or treatment of } \\
\text { asthma }\end{array}$ & 2449 & $269 / 2449(11 \%)$ & $207 / 1853(11.2 \%)$ & $62 / 596(10.4 \%)$ & 0.6019 & 2.5 \\
\hline
\end{tabular}

Data are presented as No. (\%) and mean \pm SD, or median (IQR) if not normally distributed. P values are calculated using Wald test. Abbreviations: N/A: not applicable; EU (Europid); MENA (Middle East North Africa); AC (African or Caribbean); AS (Asian); Glycated A1c corresponds to the glycated hemoglobin determined in the 6 months prior to or in the first 7 days following hospital admission; COPD, chronic obstructive pulmonary disease; OSA, obstructive sleep apnea; NAFLD, non-alcoholic fatty liver disease; DPP4-inhibitors, Dipeptidyl peptidase 4-inhibitors; GLP-1RA, Glucagon-Like Peptide 1-Receptor Agonist; MRA, Mineralocorticoid Receptor Agonist; ARB, angiotensin-2 receptor blocker; ACE-Inhibitors, angiotensin converting enzymeinhibitors; SMD, Standardized Mean Difference

$\uparrow$ Microvascular complication was defined as history of one or more of the following: diabetic kidney disease and/or severe diabetic retinopathy and/or diabetic foot ulcer

* Macrovascular complication was defined as history of one or more of the following comorbidities: acute coronary syndrome, coronary artery disease revascularization, transient ischemic attack and/or lower limber artery revascularization

§Thiazide diuretics, and potassium-sparing diuretics.

Table 2. COVID-19-related clinical, radiological and biological characteristics on admission of CORONADO participants according to the use of DPP-4 inhibitors.

\begin{tabular}{|c|c|c|c|c|c|c|}
\hline \multirow{2}{*}{ Clinical features } & \multirow{2}{*}{$\begin{array}{l}\text { People with } \\
\text { available data }\end{array}$} & \multirow{2}{*}{ All } & \multicolumn{2}{|c|}{$\begin{array}{l}\text { DPP4-inhibitor before } \\
\text { admission }\end{array}$} & \multirow{2}{*}{$\begin{array}{c}P \\
\text { value }\end{array}$} & \multirow{2}{*}{$\begin{array}{c}S M \\
D\end{array}$} \\
\hline & & & $\begin{array}{c}\text { No }(n= \\
1853)\end{array}$ & $\begin{array}{c}\text { Yes }(\mathrm{n}= \\
596)\end{array}$ & & \\
\hline Positive SARS-CoV-2 PCR & 2374 & $\begin{array}{c}2245 / 2374 \\
(94.6 \%)\end{array}$ & $\begin{array}{c}1704 / 1802 \\
(94.6 \%)\end{array}$ & $\begin{array}{l}541 / 572 \\
(94.6 \%)\end{array}$ & $\begin{array}{c}0.98 \\
62 \\
\end{array}$ & 0.1 \\
\hline COVID-19 symptoms & 2448 & $\begin{array}{c}2317 / 2448 \\
(94.6 \%)\end{array}$ & $\begin{array}{c}1753 / 1852 \\
(94.7 \%)\end{array}$ & $\begin{array}{l}564 / 596 \\
(94.6 \%)\end{array}$ & $\begin{array}{c}0.98 \\
23\end{array}$ & 0.1 \\
\hline $\begin{array}{r}\text { Time between symptom onset and hospital } \\
\text { admission (days) }\end{array}$ & 2399 & $5[2 ; 8]$ & $5[2 ; 8]$ & $6[2 ; 9]$ & $\begin{array}{c}0.01 \\
62 \\
\end{array}$ & $\begin{array}{c}11 . \\
5\end{array}$ \\
\hline \multicolumn{7}{|l|}{ Clinical presentation } \\
\hline Fever & 2414 & $\begin{array}{c}1807 / 2414 \\
(74.9 \%)\end{array}$ & $\begin{array}{c}1366 / 1827 \\
(74.8 \%)\end{array}$ & $\begin{array}{l}441 / 587 \\
(75.1 \%)\end{array}$ & $\begin{array}{c}0.86 \\
1\end{array}$ & 0.8 \\
\hline Fatigue & 2337 & $\begin{array}{c}1456 / 2337 \\
(62.3 \%)\end{array}$ & $\begin{array}{c}1075 / 1770 \\
(60.7 \%)\end{array}$ & $\begin{array}{l}381 / 567 \\
(67.2 \%)\end{array}$ & $\begin{array}{c}0.00 \\
58\end{array}$ & $\begin{array}{c}13 . \\
5\end{array}$ \\
\hline Cough & 2383 & $\begin{array}{c}1606 / 2383 \\
(67.4 \%)\end{array}$ & $\begin{array}{c}1213 / 1799 \\
(67.4 \%)\end{array}$ & $\begin{array}{l}393 / 584 \\
(67.3 \%)\end{array}$ & $\begin{array}{c}0.95 \\
29\end{array}$ & 0.3 \\
\hline Cephalalgia & 2263 & $\begin{array}{c}283 / 2263 \\
(12.5 \%)\end{array}$ & $\begin{array}{c}216 / 1714 \\
(12.6 \%)\end{array}$ & $\begin{array}{l}67 / 549 \\
(12.2 \%)\end{array}$ & $\begin{array}{c}0.80 \\
61\end{array}$ & 1.2 \\
\hline Dyspneoa & 2416 & $\begin{array}{c}1562 / 2416 \\
(64.7 \%)\end{array}$ & $\begin{array}{c}1183 / 1834 \\
(64.5 \%)\end{array}$ & $\begin{array}{l}379 / 582 \\
(65.1 \%)\end{array}$ & $\begin{array}{c}0.78 \\
64\end{array}$ & 1.3 \\
\hline Rhinitis and/or pharyngeal signs & 2227 & $\begin{array}{c}181 / 2227 \\
(8.1 \%)\end{array}$ & $\begin{array}{c}143 / 1686 \\
(8.5 \%)\end{array}$ & $\begin{array}{l}38 / 541 \\
(7.0 \%)\end{array}$ & $\begin{array}{c}0.28 \\
11\end{array}$ & 5.5 \\
\hline Agueusia and/or Anosmia & 2129 & $\begin{array}{c}298 / 2129 \\
(14.0 \%)\end{array}$ & $\begin{array}{c}226 / 1602 \\
(14.1 \%)\end{array}$ & $\begin{array}{l}72 / 527 \\
(13.7 \%)\end{array}$ & $\begin{array}{c}0.79 \\
84\end{array}$ & 1.3 \\
\hline Digestive disorders & 2336 & $\begin{array}{c}775 / 2336 \\
(33.2 \%) \\
\end{array}$ & $\begin{array}{c}584 / 1770 \\
(33.0 \%) \\
\end{array}$ & $\begin{array}{l}191 / 566 \\
(33.7 \%) \\
\end{array}$ & $\begin{array}{c}0.74 \\
11 \\
\end{array}$ & 1.6 \\
\hline \multicolumn{7}{|l|}{ Chest CT imaging } \\
\hline Abnormal chest $\mathrm{CT}$ & 1735 & $\begin{array}{c}1675 / 1735 \\
(96.5 \%)\end{array}$ & $\begin{array}{c}1245 / 1290 \\
(96.5 \%)\end{array}$ & $\begin{array}{l}430 / 445 \\
(96.6 \%)\end{array}$ & $\begin{array}{c}0.90 \\
68\end{array}$ & 0.6 \\
\hline Ground-glass opacity/crazy paving & 1712 & $\begin{array}{c}1548 / 1712 \\
(90.4 \%) \\
\end{array}$ & $\begin{array}{c}1145 / 1270 \\
(90.2 \%) \\
\end{array}$ & $\begin{array}{l}403 / 442 \\
(91.2 \%) \\
\end{array}$ & $\begin{array}{c}0.53 \\
09 \\
\end{array}$ & 3.5 \\
\hline \multicolumn{7}{|l|}{ Biological findings } \\
\hline Admission plasma glucose $(\mathrm{mg} / \mathrm{dL})$ & 1834 & $\begin{array}{c}170[127 ; \\
236]\end{array}$ & $\begin{array}{c}167[125 ; \\
229]\end{array}$ & $\begin{array}{c}185[131 ; \\
256]\end{array}$ & $\begin{array}{c}0.00 \\
63\end{array}$ & $\begin{array}{c}12 . \\
7\end{array}$ \\
\hline
\end{tabular}




\begin{tabular}{|c|c|c|c|c|c|c|c|}
\hline & eGFR (CKD-EPI) $\left(\mathrm{mL} / \mathrm{min} / 1.73 \mathrm{~m}^{2}\right)$ & 2287 & $\begin{array}{c}67.2[41.0 ; \\
88.5]\end{array}$ & $\begin{array}{c}67.1[40.5 \\
88.3]\end{array}$ & $\begin{array}{c}67.8[42.5 \\
89.3]\end{array}$ & $\begin{array}{c}0.12 \\
67\end{array}$ & 4.5 \\
\hline & ALT (\%ULN) & 2056 & $\begin{array}{c}0.61[0.42 \\
0.98]\end{array}$ & $\begin{array}{c}0.61[0.42 \\
0.98]\end{array}$ & $\begin{array}{c}0.62[0.42 \\
1.00]\end{array}$ & $\begin{array}{c}0.98 \\
31\end{array}$ & 5.3 \\
\hline & AST (\%ULN) & 2023 & $\begin{array}{c}1.06[0.75 \\
1.59]\end{array}$ & $\begin{array}{c}1.06[0.75 ; \\
1.60]\end{array}$ & $\begin{array}{c}1.06[0.75 \\
1.55]\end{array}$ & $\begin{array}{c}0.41 \\
04\end{array}$ & 6.3 \\
\hline & GGT (\%ULN) & 1915 & $\begin{array}{c}0.93[0.55 \\
1.73]\end{array}$ & $\begin{array}{c}0.94[0.55 \\
1.75]\end{array}$ & $\begin{array}{c}0.92[0.58 \\
1.68]\end{array}$ & $\begin{array}{c}0.92 \\
34\end{array}$ & 0.5 \\
\hline & Hemoglobin $(\mathrm{g} / \mathrm{dL})$ & 2387 & $\begin{array}{c}12.7[11.4 \\
14.2]\end{array}$ & $\begin{array}{c}12.7[11.4 \\
14.2]\end{array}$ & $\begin{array}{c}12.7[11.4 \\
14.1]\end{array}$ & $\begin{array}{c}0.81 \\
44\end{array}$ & 0.3 \\
\hline & White cell count $\left(10^{3} / \mathrm{mm} 3\right)$ & 2384 & $\begin{array}{c}6600[5000 \\
8820]\end{array}$ & $\begin{array}{c}6530[5000 \\
8890]\end{array}$ & $\begin{array}{c}6685[4985 \\
8718]\end{array}$ & $\begin{array}{c}0.56 \\
08\end{array}$ & 3.1 \\
\hline & Lymphocyte count $\left(10^{3} / \mathrm{mm}^{3}\right)$ & 2313 & $\begin{array}{c}990[690 ; \\
1400]\end{array}$ & $\begin{array}{c}1000[690 \\
1422]\end{array}$ & $\begin{array}{c}920 \text { [690; } \\
1300]\end{array}$ & $\begin{array}{c}0.13 \\
22\end{array}$ & 1.7 \\
\hline \multirow{6}{*}{0} & Platelet count $\left(10^{3} / \mathrm{mm} 3\right)$ & 2383 & $\begin{array}{c}201[155 ; \\
258]\end{array}$ & $\begin{array}{c}201[155 ; \\
258]\end{array}$ & $\begin{array}{c}201[156 ; \\
260]\end{array}$ & $\begin{array}{c}0.14 \\
25\end{array}$ & 4.8 \\
\hline & D-dimers $(\mu \mathrm{g} / \mathrm{L})$ & 957 & $\begin{array}{c}880[328 ; \\
1730]\end{array}$ & $\begin{array}{c}820[300 ; \\
1670]\end{array}$ & $\begin{array}{c}1000[430 \\
1894]\end{array}$ & $\begin{array}{c}0.24 \\
84\end{array}$ & 7.8 \\
\hline & $\mathrm{CRP}(\mathrm{mg} / \mathrm{L})$ & 2286 & $\begin{array}{c}86[40.8 ; \\
146.9]\end{array}$ & $\begin{array}{c}83.6[38.2 ; \\
144]\end{array}$ & $\begin{array}{c}92.8[47.5 \\
149.2]\end{array}$ & $\begin{array}{c}0.00 \\
3\end{array}$ & 5.3 \\
\hline & LDH (UI/L) & 1253 & $\begin{array}{c}350[262 \\
494]\end{array}$ & $\begin{array}{c}349[256 \\
485]\end{array}$ & $\begin{array}{c}351[273 \\
500]\end{array}$ & $\begin{array}{c}0.91 \\
1\end{array}$ & 0.4 \\
\hline & $\mathrm{CPK}(\mathrm{UI} / \mathrm{L})$ & 1207 & $132[66 ; 302]$ & $134[65 ; 326]$ & $\begin{array}{c}118[67 ; \\
252]\end{array}$ & $\begin{array}{c}0.33 \\
42\end{array}$ & 8.0 \\
\hline & Fibrinogen $(\mathrm{g} / \mathrm{L})$ & 1227 & $6.2[5.0 ; 7.4]$ & $6.2[5.0 ; 7.4]$ & $6.2[5.0 ; 7.2]$ & $\begin{array}{c}0.68 \\
84\end{array}$ & 5.5 \\
\hline
\end{tabular}

I ata are presented as No. (\%) and mean $\pm \mathrm{SD}$, or median (IQR) if not normally distributed. P values are calculated using Wald test. Quantitative ariables were natural $\log$ transformed and associated OR correspond to an increase of $1 \mathrm{SD}$ after standardization, except for time between symptoms onset and hospital admission (1-day increase).

Abbreviations: CT, computed tomography; eGFR, estimated glomerular filtration rate, according to the CKD-EPI formula; ALT, alanine aminotransferase; AST, aspartate aminotransferase; GGT, gamma-glutamyl transferase; CRP, C-reactive protein; LDH, lactate dehydrogenase; CPK, cram phosphokinase; ULN, Upper limit of normal; SMD, Standardized Mean Difference

Table 3: Association between the use vs no use of DPP-4 inhibitor and outcomes estimated in logistic regression models weighted by patients' inverse probability of treatment ( $n=2449$, imputed sample). (1)

\begin{tabular}{|l|l|c|c|c|c|c|c|}
\hline & \multicolumn{5}{|c|}{ Day 7 } & \multicolumn{3}{c|}{ Day 28 } \\
\hline & $\begin{array}{c}\text { Model M0 } \\
\text { Baseline } \\
\text { parameters }\end{array}$ & $\begin{array}{c}\text { Model M1 } \\
\text { M0 + eGFR } \\
\text { using CKD- } \\
\text { EPI }\end{array}$ & $\begin{array}{c}\text { Model M2 } \\
\text { M1 + diabetes } \\
\text { duration + } \\
\text { HbA }_{\mathbf{1 c}}\end{array}$ & $\begin{array}{c}\text { Model M0 } \\
\text { Baseline } \\
\text { parameters }\end{array}$ & $\begin{array}{c}\text { Model M1 } \\
\text { M0 + eGFR } \\
\text { using CKD- } \\
\text { EPI }\end{array}$ & $\begin{array}{c}\text { Model M2 } \\
\text { M1 + diabetes } \\
\text { duration + } \\
\text { HbA }_{\mathbf{1 c}}\end{array}$ \\
\hline $\begin{array}{l}\text { DPP4-inh } \\
\text { user/pop. size }\end{array}$ & \multicolumn{7}{|c|}{$\mathbf{5 9 6 / 2 4 4 9} \mathbf{( 2 4 \% )}$} \\
\hline $\begin{array}{l}\text { Primary } \\
\text { outcome }\end{array}$ & $0.95[0.77-1.17]$ & $0.94[0.76-1.16]$ & $0.93[0.75-1.15]$ & $0.96[0.78-1.17]$ & $0.94[0.77-1.15]$ & $0.93[0.76-1.14]$ \\
\hline $\begin{array}{l}\text { Tracheal } \\
\text { intubation }\end{array}$ & $0.93[0.73-1.18]$ & $0.94[0.74-1.19]$ & $0.93[0.73-1.18]$ & $0.97[0.77-1.22]$ & $0.97[0.77-1.23]$ & $0.97[0.77-1.23]$ \\
\hline Death & $0.99[0.73-1.34]$ & $0.96[0.71-1.30]$ & $0.95[0.70-1.29]$ & $0.94[0.74-1.18]$ & $0.90[0.71-1.14]$ & $0.89[0.70-1.12]$ \\
\hline
\end{tabular}

OR $[95 \% \mathrm{CI}]$ for primary outcome (tracheal intubation for assisted mechanical ventilation and death), tracheal intubation and death. 